Balázs Bartóki-Gönczy

\title{
REGULATION OF SOCIAL MEDIA PLATFORMS IN THE EUROPEAN UNION
}

Balázs Bartóki-Gönczy, Assistant Professor, University of Public Service, Faculty of Public Governance and International Studies, Department of Social Communication, bartoki-gonczy.balazs@uni-nke.hu

Social media platforms are mainly characterised by private regulation. ${ }^{1}$ However, their direct and indirect impact on society has become such (fake news, hate speech, incitement to terrorism, data protection breaches, impact on the viability of professional journalism) that private regulatory mechanisms in place (often opaque and not transparent) seem to be inadequate. In the present paper, I would first address the problem of the legal classification of these services (media service provider vs. intermediary service provider), since the answer to this question is a prerequisite for any state intervention. I would then present the regulatory initiatives (with a critical approach) at the EU and national level which might shape the future of 'social media platform' regulation.

KeYwords:

social media platform, freedom of speech, regulation, digital services act, media regulation

In the context of the present study, we mean private regulation as a set of rules applied by platforms to their own activities. By contrast, self-regulation is defined as the rules for private market participants being laid down by an independent body separate from them but composed of their members. Co-regulation is understood as a system where the State cooperates with representative bodies of private entities. We mean co-regulation where the state defines the frame of the rules defined by private operators and controls their execution. 


\section{INTRODUCTION}

Social networks allow any citizen to publish the content of their choice and share it with other network users. They have revolutionised the media industry and the ways of communication by offering citizens and civil society a medium for direct expression. The possibility for citizens to exercise their freedoms of expression, communication and information are therefore considerably increased by these services. However, the capabilities offered by social networks give rise to unacceptable abuses of these freedoms. These abuses are committed by isolated individuals or organised groups to which large social networks, including Facebook, YouTube, Twitter or Snapchat, to name a few, have not answered satisfactorily for to date. However, by their policy of moderation, social networks are able to act directly on these most obvious abuses to prevent or respond to them and thus, limit damage in terms of social cohesion. ${ }^{2}$

Even Mark Zuckerberg (CEO of Facebook) has recognised that "we need an active role for governments and regulators. By updating the rules for the Internet, we can reserve what's best about it - the freedom for people to express themselves and for entrepreneurs to build new things - while also protecting society from broader harm". ${ }^{3}$

The challenge is how we can ensure the right to access to information and at the same time protect the users from online abuses. From a legal point of view, how should we define and regulate social media platforms? In this paper I aim to highlight some of these legal challenges and show the most likely way the EU will go on with the revision of the Electronic Commerce Directive (hereinafter: E-Commerce Directive). ${ }^{4}$

\section{LEGAL CLASSIFICATION OF THE SOCIAL MEDIA SERVICE}

\subsection{The evolution of the audiovisual media services approach}

Large Internet gatekeepers consider themselves tech companies. As Koltay mentions, it is in their best interest to do so, for two reasons. First, the regulations applicable to technology companies are far narrower and less stringent than those applicable to media companies (which are also subject to content regulation, special restriction on competition, the prohibition of concentration and the obligation to perform public interest tasks). Second,

2 Créer un cadre français de responsabilisation des réseaux sociaux: agir en France avec ambition européenne. Rapport de la mission 'Régulation des réseaux sociaux - Expérimentation Facebook', Secrétaire d'État chargé du numérique, 2019.

3 Mark Zuckerberg, 'The Internet Needs New Rules. Let's Start in These Four Areas', The Washington Post, 30 March 2019.

4 Directive 2000/31/EC of the European Parliament and of the Council of 8 June 2000 on certain legal aspects of information society services, in particular electronic commerce, in the Internal Market ('Directive on electronic commerce'), OJ L 178. 
the moral requirement of social responsibility is far less frequently mentioned concerning the activities of tech companies.

The E-Commerce Directive and the Audiovisual Media Services Directive (hereinafter: AVMS Directive) $)^{5}$ seek to separate information society services from media services. According to the E-Commerce Directive, a service whereby the service provider selects or modifies the information transmitted is not an information society service within the scope of the Directive. On the other hand, the AVMS Directive excludes from its scope services that do not have 'effective control' over the content in question.

However, as a result of convergence, it is becoming increasingly difficult to determine clearly whether an online intermediary activity involves 'selection' of content or exercising 'effective control' over it. ${ }^{6}$ It is enough to think only about content selection by algorithms. The EU legislator also seeks to adapt flexibly to the challenges of the age and to dynamically shape the concept of media service. Therefore, where the concept of media service is constantly expanding, the most delicate question is where to draw the line. It is unclear whether Facebook and other social media are still 'technical' mediators or they behave more like 'media' service. To determine this, we will analyse below the concept of dynamically changing media services, with particular reference to the future classification of social media services and video sharing platforms.

The scope of media services has been expanding over the last 30 years, albeit with cautious steps, but also in order to keep pace with the changing market environment, consumer habits and technological developments. The concept, codified in the AVMS Directive adopted in 2010, makes the editorial responsibility the heart of the definition. According to the Directive, audiovisual media service is:

A service as defined by Articles 56 and 57 of the Treaty on the Functioning of the European Union which is under the editorial responsibility of a media service provider and the principal purpose of which is the provision of progrAVMS, in order to inform, entertain or educate, to the general public by electronic communications networks within the meaning of point (a) of Article 2 of Directive $2002 / 21 /$ EC. Such an audiovisual media service is either a television broadcast as defined in point (e) of this paragraph or an on-demand audiovisual media service as defined in point $(\mathrm{g})$ of this paragraph $(. . .)^{7}$

'Editorial responsibility' means the exercise of effective control both over the selection of the programmes and over their organisation either in a chronological schedule, in case

Directive 2010/13/EU of the European Parliament and of the Council of 10 March 2010 on the coordination of certain provisions laid down by law, regulation or administrative action in Member States concerning the provision of audiovisual media services ('Audiovisual Media Services Directive'), OJ L 95.

6 Tamás Klein, 'Adalékok az online diskurzusok szabályozási kérdéseihez', in Sajtószabadság és médiajog a 21. század elején, ed. by András Koltay and Bernát Török (Budapest: Wolters Kluwer, 2017), 156.

Directive 2010/13/EU, Art. 1, point 1a) (emphasis added). 
of television broadcasts, or in a catalogue, as in case of on-demand audiovisual media services. Editorial responsibility does not necessarily imply any legal liability under national law for the content or the services provided. ${ }^{8}$ The Directive of 2010 does not further clarify what is meant by 'selection', but in practice there may be several cases where the answer to the question is unclear.

Therefore, the Directive of 2010 excluded many services from its scope. According to its audiovisual media service definition, it covered only audiovisual media services intended for the general public and having a clear influence on it, excluding, inter alia, private websites and services in which individuals make their own audiovisual content (for example, social media service providers).

In recent years, the EU legislature itself has recognised the need to adapt the material scope of media regulation to a rapidly changing reality. According to the European Digital Single Market Strategy adopted in 2015, ${ }^{9}$ the AVMS Directive needs to be updated to reflect these changes in the market, consumption and technology. On 25 May 2016, the Commission published its Amending Proposal ('the Proposal') ${ }^{10}$ explaining that the reason for the change was the emergence of new business models, which allowed new, growing players on the Internet to compete for the same audience (for example, videoon-demand service providers and video sharing platforms) offering audiovisual content. However, the Commission notes that television broadcasting, on-demand video and user-generated content are subject to different rules and that there are different levels of consumer protection.

The modification of the AVMS Directive was adopted in Fall 2018. ${ }^{11}$ In terms of its scope, it represents two important changes to the Directive of 2010. The first, that the criterion of 'editorial responsibility' loses its significance in the concept of media service, focuses on the 'primary purpose' of the service:

'Audiovisual media service' means: a service (...) where the principal purpose of the service or a dissociable section thereof is devoted to providing progrAVMS, under the editorial responsibility of a media service provider, to the general public, in order to inform, entertain or educate, by means of electronic communications networks $(\ldots) .^{12}$

\footnotetext{
Directive 2010/13/EU, Art. 1, point 1c).

Digital Single Market Strategy for Europe, SWD(2015) 100 final.

$\operatorname{COM}(2016) 287$ final, 2.

Directive (EU) 2018/1808 of the European Parliament and of the Council of 14 November 2018 amending Directive 2010/13/EU on the coordination of certain provisions laid down by law, regulation or administrative action in Member States concerning the provision of audiovisual media services ('Audiovisual Media Services Directive') in view of changing market realities, OJ L 303.

12 Directive 2018/1808, Art.1.
} 
The biggest change, however, is the point in the amendment that extends the scope of media regulation to online 'video sharing platforms' (with less burden compared to audiovisual media services):

'Video-sharing platform service' means a service as defined by Articles 56 and 57 of the Treaty on the Functioning of the European Union, where the principal purpose of the service or of a dissociable section thereof or an essential functionality of the service is devoted to providing progrAVMS, user-generated videos, or both, to the general public, for which the video-sharing platform provider does not have editorial responsibility, in order to inform, entertain or educate, by means of electronic communications networks within the meaning of point (a) of Article 2 of Directive 2002/21/EC and the organization of which is determined by the video-sharing platform provider, including by automatic means or algorithms in particular by displaying, tagging and sequencing. ${ }^{13}$

\subsection{What about social media services?}

According to the original Commission proposal, ${ }^{14}$ social media services fall within the scope of the AVMS Directive only if they provide a service that meets the definition of a video-sharing platform. According to the Council's amendment proposals adopted in March 2017, social media has become an important tool for information sharing, entertainment and education. Therefore, the Council argues that social media platforms should be subject to media regulation where audiovisual content represents a significant proportion of the social media interface.

To determine what constitutes 'a significant part', it is necessary to consider 1 . whether the service provider has developed a separate business model for contents shared by third parties or by itself and 2. it is important to consider how audiovisual content is displayed.

I agree with this position since the social media service providers, such as Facebook, are increasingly taking on the role of 'editor', having significant and direct discretion in deciding what content may appear in users' 'daily news'. ${ }^{15}$ It is a well-known fact that Facebook, Twitter, Snapchat and Instagram employ a dedicated editorial team to select the content available on their site. ${ }^{16}$ Twitter CEO Jack Dorsey himself stated in 2016 that 'we recruited people to help us select the best tweets for Moments (...)'. ${ }^{17}$

Directive 2018/1808, Art. 1.

$\operatorname{COM}(2016) 287$ final, recital 3.

Balázs Bartóki-Gönczy, The online intermediaries as new gatekeepers of the access to information (Budapest: Pázmány Press, 2018), 31.

16 It is important to note, however, that the moderation of content on these sites and the editing of the news feed are governed by pre-written algorithms, as the huge amount of data can no longer be handled otherwise.

17 Lucie Ronfaut, Enguérand Renault and Benjamin Ferran, 'Jack Dorsey (Twitter): «Les annonceurs attendent beaucoup de la vidéo»', Le Figaro, 12 May 2016. 
This is linked to the controversy surrounding Facebook's 'Trending Stories' service launched in 2014. This 'box' at the top of the sidebar of the feed was intended to display the most current and recent news and highlighted in this section the news that was read and shared by many. What was important and interesting was not determined by algorithms, but by an editorial team. In addition, in gradually leaked documents, ${ }^{18}$ statements by insiders and former editors revealed that the selection of news had overtaken conservative sources and the Liberals were clearly favoured by an editorial team whose subjective decisions were based on written instruction. So the problem was not only that, despite Facebook's assertions, it was edited selectively, but that it was done with bias. Facebook first denied the allegations, but later admitted that the personal bias of the editors could indeed have distorted the selection of news.

In addition to his assumed editorial role, the so-called 'fake news phenomenon' may also force social media service providers to take on new roles beyond that of the technical mediation provider. It is suspected that the Russian Federation has used the most popular social media providers as a tool to influence the U.S. presidential election in 2016. The case may have shocked Facebook itself, which first denied that its platform was appropriate for engaging in social debate at this level, but was forced to admit, after an internal investigation, that Russian propaganda reached about 126 million (!) U.S. citizens through the social media site. ${ }^{19}$ Social media (or Facebook in particular) has a disillusioning power, and the influence and exposure of the public to fake news in the feed is a cause for concern. It has become clear that the vast majority of the population will indiscriminately indulge in everything they read through Facebook. In response, Mark Zuckerberg announced in October 2017 that they would tighten their rules on sponsored content. First, they have increased transparency by displaying the advertiser alongside supported content and what other advertisers are paying for on Facebook..$^{20}$

In my view, these steps point to the fact that social media service providers, due to their indisputably important role and responsibility in social debate, are taking on a number of editorial tasks, simply being no more than technical service providers. This approach is shared by Potier and Abiteboul, who consider that all content published on a social network cannot be presented to the user without scheduling. The volume of content published implies that the platform defines an order of appearance, makes a selection, while leaving the user the possibility of searching, at his/her initiative, specific content. The content that the user will actually consult will primarily depend on the layout of its interface and the use of algorithmic rules to prioritise and individualise the presentation of the different content. The existence of this information structuring function plays an

18 Sam Thielman, 'Facebook news selection is in hands of editors not algorithms, documents show', The Guardian, 12 May 2016.

19 Julian Borger, Lauren Gambino and Sabrina Siddiqui, 'Tech giants face Congress as showdown over Russia election meddling looms', The Guardian, 22 October 2017.

20 Prayank, '5 Ways Facebook Will Improve Transparency in Ads and Avoid Fake News', Guiding Tech, 03 October 2017. 
essential role in the dissemination of content and in the capacity of social networks to prevent or accentuate damage to social cohesion. The observation of the existence of this content scheduling function, which constitutes a de facto editorial form, cannot call into question the legal status of these actors, nor lead to them requalify as publishers when the majority of social network services do not select prior to the publication of content. ${ }^{21}$

\section{FIGHT AGAINST ILLEGAL CONTENT ON SOCIAL MEDIA NETWORKS}

\subsection{Responsibility in general of social media service providers for illegal content}

Despite the tendencies described above, under EU law, social media platforms are still considered to be 'hosting service providers', as the users of such services store, sort and make available their own content in and through the systems. This means that, pursuant to the E-Commerce Directive, the platforms are required to remove any illegal content after they become aware of its infringing nature, but they may not be subject to any general monitoring and control obligation. ${ }^{22}$

Nevertheless, a tendency to challenge this principle could be observed recently. The Court of Justice of the European Union (hereinafter: CJEU), in its judgment C-18/18 of 3 October 2019, ruled that the Directive does not preclude a national court to order a host provider to remove content identical or equivalent to a message previously declared unlawful, provided that the message 1 . remains essentially unchanged and 2 . does not require an independent assessment from the host provider. ${ }^{23}$ As the CJEU notes, 'although Article 15(1) [of the E-Commerce Directive] prohibits Member States from imposing on host providers a general obligation to monitor information which they transmit or store, or a general obligation actively to seek facts or circumstances indicating illegal activity (...), such a prohibition does not concern the monitoring obligations 'in a specific case.'.24

Such a specific case may be found, in particular piece of information stored by the host provider concerned at the request of a certain user of its social network, the content of which was examined and assessed by a court having jurisdiction in the Member State, which, following its assessment, declared it to be illegal. According to the CJEU, in order to ensure that the host provider at issue prevents any further impairment of the interests involved, it is legitimate for the court having jurisdiction to be able to require that host provider to block access to the information stored, the content of which is identical to the

${ }^{21}$ Créer un cadre français de responsabilisation des réseaux sociaux: agir en France avec ambition européenne, $2019,9$.

22 András Koltay, New Media and Freedom of Expression: Rethinking the Constitutional Foundations of the Public Sphere (Hart Publishing, 2019), 87.

23 'Blocking access to content previously declared unlawful: a new obligation for online platforms?', Epra, 15 January 2020.

24 Judgment of the Court In Case C-18/18, point 34. 
content previously declared to be illegal. In particular, in view of the identical content of the information concerned, the injunction granted for that purpose cannot be regarded as imposing an obligation on the host provider to generally monitor the information which it stores, or a general obligation to actively seek facts or circumstances indicating illegal activity. ${ }^{25}$

\subsection{Germany}

Germany was the first European state who adopted, in 2017, a sui generis act on social media service providers aiming to 'improve enforcement of the law in social media networks' (hereinafter: NetzDG). ${ }^{26}$ The Act applies to 'telemedia service providers' which, for profitmaking purposes, operate internet platforms which are designed to enable users to share any content with other users or to make such content available to the public (social networks). Platforms offering journalistic or editorial content, the responsibility for which lies with the service provider itself, shall not constitute social networks within the meaning of this Act. The same shall apply to platforms which are designed to enable individual communication or the dissemination of specific content. The Act applies only to social media network providers having more than two million registered users in the Federal Republic of Germany. ${ }^{27}$ The NetzDG imposes obligations in two important areas: 1. reporting and 2. handling of complaints about unlawful content.

As far as the reporting obligation is concerned, it applies to providers of social networks which receive more than 100 complaints per calendar year about unlawful content. The service providers concerned are obliged to produce semi-annual German language reports on the handling of complaints about unlawful content on their platforms and shall be obliged to publish these reports in the Federal Gazette and on their own website no later than one month after the time period concerned has ended. The reports published on their own website shall be easily recognisable, directly accessible and permanently available. The reports shall cover:

- general observations outlining the efforts undertaken by the provider of the social network to eliminate criminally punishable activity on the platform

- description of the mechanisms for submitting complaints about unlawful content and the criteria applied in deciding whether to delete or block unlawful content

- number of incoming complaints about unlawful content in the reporting period, broken down according to whether the complaints were submitted by complaints bodies or by users, and according to the reason for the complaint

Judgment of the Court In Case C-18/18, points 35-37.

Act to Improve Enforcement of the Law in Social Networks (Network Enforcement Act), 12 July 2017.

NetzDG, Art. 1. 
- organisation, personnel resources, specialist and linguistic expertise in the units responsible for processing complaints, as well as training and support of the persons responsible for processing complaints

- membership of industry associations with an indication as to whether these industry associations have a complaints service

- number of complaints for which an external body was consulted in preparation for making the decision

- number of complaints in the reporting period that resulted in the deletion or blocking of the content at issue

- time between complaints being received by the social network and the unlawful content being deleted or blocked

- measures to inform the person who submitted the complaint and the user for whom the content at issue was saved, about the decision on the complaint

The best evidence to date about the specific effects of NetzDG comes from the law's transparency requirements. Four major online platforms released their first transparency reports in June 2018: Google (that is, YouTube), Facebook, Twitter and Change.org. This provoked another round of debate about the law's impact and efficacy. Perhaps unsurprisingly, opinion remains divided. ${ }^{28}$ According to Heldt, after the NetzDG came into force, initial reports reveal the law's weak points, predominantly in reference to their low informative value. When it comes to important takeaways regarding new regulation against hate speech and more channelled content moderation, the reports do not live up to the expectations of German lawmakers.

Since its adoption, the NetzDG triggered fierce debate and widespread concern about its implications for freedom of expression. The first concern surrounding freedom of expression was that NetzDG would encourage the removal of legal content, also known as 'over-removal'. Online platforms, it was argued, would not have the expertise or time to assess every complaint in detail. Relatedly, critics objected to NetzDG as an instance of 'privatised enforcement' because, rather than courts or other democratically legitimated institutions, platforms assess the legality of content. The NetzDG process does not require a court order prior to content takedowns nor does it provide a clear appeals mechanism for victims to seek independent redress.

A study of the experience of the first three years of the application of the law also reveals a number of shortcomings, ${ }^{29}$ as a result of which the German Parliament passed an amending law on 6 May 2021. ${ }^{30}$ According to the amendment, ISPs will be obliged not only to delete infringing content, but will also have to forward it to a centre set up at the Federal Criminal Office (Bundeskriminalamt) with the IP addresses of the users who published

\footnotetext{
28 Heidi Tworek and Paddy Leersen, 'An Analysis of Germany's NetzDG Law', Transatlantic Working Group, 15 April 2019.

29 Martin Eifert et al., 'Evaluation des NetzD im Auftrag des BMjV', 2020.

30 Gesetzentwurf der Fraktionen der CDU/CSU und SPD, Drucksache 19/17741.
} 
the illegal content. This rule aims to make law enforcement more effective. Moreover, the amendment seeks to respond to the debate surrounding the limits of freedom of speech (for example, the questionable ban of Donald J Trump). The amendment obliges the service provider to give opportunity to object against its decision. It also obliges social media platforms providers to recognise and enforce the decisions of the various conciliation fora.

\subsection{France}

\subsubsection{The 'Trust in the Digital Economy Act'}

In 2004, the French parliament passed a law ${ }^{31}$ aimed at boosting confidence in the digital economy by transposing the provisions of the E-Commerce Directive. The law has been amended fourteen times since its entry into force in 2004 as it prescribes some special provisions not foreseen in the E-Commerce Directive:

- The exemption from content monitoring does not apply if it is specifically and periodically ordered by an investigating authority.

- The law defines crimes $^{32}$ for the prevention of which platform providers have additional responsibilities such as:

- The service provider must provide an easy-to-use and accessible reporting system for reporting these crimes.

- They are obliged to report all cases brought to their attention to the competent national authority, law enforcement body.

- They should disclose what measures have been taken against the commission of these crimes through the platform. ${ }^{33}$

- Failure to comply with the above obligations may result in a fine of EUR 15,000 or a term of imprisonment of up to one year. If the whistleblower acts in bad faith, he/she will face the same penalty.

- The authorities may, of their own motion or upon request, impose on social media service providers any measure that is appropriate to put an end to the illegal situation.

- The law obliges social media providers to retain all personal data necessary to identify the offender. These must be issued by the authorities. ${ }^{34}$

Loi n 2004-575 du 21 juin 2004 pour la confiance dans l'économie numérique.

32 Denying, glorifying, glorifying or inciting to commit crimes against humanity, incitement to hatred on the grounds of race, sexual orientation, gender, disability, child pornography, incitement (namely to sexual and sexist violence), crimes against human dignity.

33 Articles 6 and 6-1.

34 Article 6 (II). 
Since 2015, the law has specifically highlighted incitement to commit terrorist acts and their apology, as well as the crime of distributing pornographic recordings of minors. ${ }^{35}$ The removal of such content may be requested by the designated national authority (OCLCTIC) $^{36}$ from the platform provider, with simultaneous notification to the ISP. If the platform does not remove the illegal content within 24 hours, the Internet access provider is obliged to terminate access to the illegal content. However, in some cases, the authority may ask the ISP directly to block the illegal content. In parallel with the request for removal, the authority forwards the request to the 'Personne qualifiée' (PQ) designated by the French Data Protection Authority (CNIL), who indicates if he/she does not agree with the request for removal. If the Authority does not withdraw the removal request as a result, PQ may go to court. In practice, PQ is made up of CNIL staff. The detailed rules of the blocking procedure and the PQ are regulated by a decree. ${ }^{37}$ The PQ produces an annual report. According to the 2019 report, ${ }^{38}$ in 2019 the organisation examined 18,177 cases, of which none indicated disagreement (in 2018 only two cases). Interestingly in the report, 68 per cent of the cancellation requests were fulfilled by the platforms. It is important that this refusal does not entail a sanction. In the last five years, PQ has objected to the request for cancellation in 11 cases. In six cases the application was withdrawn by the authority, in one case PQ changed its decision after receiving new information, and in four cases the court ruled on the matter, in all cases in favour of PQ.

\subsubsection{Loi Avia}

In France, the question of whether the rules in force are sufficiently stringent has long been a public theme. The law passed by the French Parliament on 13 May $2020^{39}$ (the so-called Loi Avia) introduced a number of restrictions:

- Pornographic and terrorist content: platforms no longer had to remove terrorist and child pornographic content as an option (without penalty), but were obliged to do so within 1 hour, with a penalty of EUR 250,000 and one year of imprisonment.

- Other offenses: The amendment required that certain crimes defined in the Penal Code (excluding child pornography and terrorism, see above) must be removed by platform operators and search engines within 24 hours. The penalty has also been increased to EUR 250,000.

\footnotetext{
Article 6-1.

Office central de lutte contre la criminalité liée aux technologies de l'information et de la communication.

Décret $n^{\circ}$ 2015-125 du 5 février 2015 relatif au blocage des sites provoquant à des actes de terrorisme ou en faisant l'apologie et des sites diffusant des images et représentations de mineurs à caractère pornographique.

8 https://www.cnil.fr/sites/default/files/atoms/files/cnil_rapport_blocage_2019.pdf

39 Loi n 2020-766 du 24 juin 2020 visant à lutter contre les contenus haineux sur internet.
} 
The search engines and platform providers would have been designated by a regulation (specifying the minimum subscriber level, other criteria). Moreover, the Loi Avia, in order to fight against online hate speech, has foreseen the following rules:

- Set up an efficient and easy-to-use reporting system.

- The notifier must be duly informed of the notification. If the application is granted, it must be completed within 24 hours, if not, the notifier must be notified within 7 days. The right and possibility of appeal must be guaranteed.

- If content is removed, the author of the content must also be notified (if possible), giving him or her the right to appeal. This notification obligation does not apply in cases where, for example, it would delay the investigation.

- Service providers were required to follow the guidelines of the Media Authority (CSA) on the subject. They should have disclosed, in accordance with CSA guidelines, their moderation policy and their technical and human background. With regard to hate speech, the CSA would have issued an annual report on compliance with the law.

However, in a decision of the French Constitutional Council (Conseil Constitutionnel, 'the CC') of 18 June $2020,{ }^{40}$ a number of provisions of the Loi Avia adopted by the Parliament were declared unconstitutional and annulled. As far as the obligation on the removal within 1 or 24 hours is concerned, the CC acknowledged that freedom of expression may be restricted, but that it must be necessary, appropriate and proportionate to the aim pursued. According to the CC, the infringing nature of the content in question is not self-evident, its assessment is a matter for the designated authority alone. Furthermore, an appeal against a decision has no suspensory effect on enforcement and the one hour available is insufficient for a judicial decision to be made on the matter. Finally, the sanction envisaged is so significant that, overall, such a restriction on freedom of expression was deemed unconstitutional.

\subsection{The European Commission's proposal for harmonised regulation at EU level}

The European Commission has presented its proposals to regulate social media platforms. In fact, the European Commission has proposed two regulations on the $15^{\text {th }}$ of December 2020: the Digital Services Act (hereinafter: DSA) ${ }^{41}$ and the Digital Markets Act (hereinafter: DMA). ${ }^{42}$

The two proposed regulations encompass a single set of new rules applicable across the whole EU. The Commission aims to create a safer digital space in which the fundamental

Décision n 2020-801 DC du 18 juin 2020 du Conseil Constitutionnel de la République Française.

41 Proposal for a regulation of the European Parliament and of the Council on a Single Market for Digital Services ('Digital Services Act') and amending Directive 2000/31/EC, COM(2020) final, 2020/0361(COD).

42 Proposal for a regulation of the European Parliament and of the Council on contestable and fair markets in the digital sector ('Digital Markets Act'), COM(2020) final, 2020/0374(COD). 
rights of all users of digital services are protected and to establish a level playing field to foster innovation, growth and competitiveness, both in the European Single Market and globally.

The DSA is the renewal of the 20 years old E-Commerce Directive. It would introduce many new obligations on online platforms, such as transparency reporting obligations, cooperation with national authorities, designation of points of contact, stricter rules on consumer protection, and so on. The DMA is a competition law tool that provides for ex ante regulation of large online platforms acting as gatekeepers (for example, Facebook, Google). The initiative aims to ensure that gateway platforms operate in a transparent manner (without hampering market competition) and offer consumers the widest possible choice. The aim is for the internal market to remain competitive and open to innovation. Although at the time of the writing of this paper many questions are still to be cleared, it is certain that the DSA and DMA might be the basis of online platform regulation in the European Union.

The general objective of the intervention is to ensure the proper functioning of the single market, in particular in relation to the provision of cross-border digital services. The Commission has identified in the impact assessment of the proposal four specific objectives. The first is to ensure the best conditions for innovative cross-border digital services to develop. The aim is to ensure legal clarity and proportionality of obligations accounting for the differences in capability, resources but also impacts and risks raised by small, emerging services compared to very large, established ones. The second objective is to maintain a safe online environment, with responsible and accountable behaviour from digital services, and online intermediaries in particular. The DSA proposal aims at providing the legal clarity for online intermediaries, and in particular online platforms, to play their role in ensuring that their services are not misused for illegal activities and that the design of their systems does not lead to societal harms. The third objective is to empower users and protect fundamental rights, and freedom of expression in particular. The aim of this objective is to ensure clear and proportionate responsibilities for authorities as well as private companies, to safeguard freedom of expression online by establishing rules that do not inadvertently lead to the removal of information that is protected by the right to freedom of expression and that speech is not stifled or dissuaded online. Finally, the proposal aims to establish the appropriate supervision of online intermediaries and cooperation between authorities. This will require the best possible cooperation among all EU Member States, ensuring both an effective supervision and creating the best conditions for innovative services to emerge, as per the first specific objective. ${ }^{43}$

$43 \quad 2020 / 0361 / C O D, 36-37$. 


\section{CONCLUSIONS}

Social media services are difficult to integrate into the existing legal conceptual framework. While, de facto, more and more editorial activities are being performed (directly or through algorithms), social media service remains, de lege, a hosting service under EU law. However, the revision of the AVMS Directive has made it possible to extend the scope of media regulation to social media services in respect of elements of the service that meet the Directive's video-sharing platform concept. Due to the growing impact of social media in our society, the effective removal of infringing content has become a top priority. This issue is also sensitive because action against allegedly infringing content should not lead to a disproportionate interference with freedom of expression. The noticeand-take-down rules of the E-Commerce directive are outdated and will be reviewed this year at the EU level. The proposal of the European Commission leads to a more robust and uniform regulation but in the actual phase of the legislative procedure many questions remain unanswered and many provisions have to be clarified in order to avoid uncertainty when applying the regulation. It will also be interesting to see whether the national laws regulating social media platforms will remain in force or will be completely replaced by the new regulation. I do believe that it would be reasonable to resolve all issues at $\mathrm{EU}$ level, but if the final regulation does not achieve the desired goals, there is still the possibility of regulating the platforms at national level, as the example of Germany shows. 


\section{REFERENCES}

1. Act to Improve Enforcement of the Law in Social Networks (Network Enforcement Act), 12 July 2017. Online: www.bmjv.de/SharedDocs/Gesetzgebungsverfahren/ Dokumente/NetzDG_engl.pdf?__blob=publicationFile\&v=2

2. Bartóki-Gönczy, Balázs, The online intermediaries as new gatekeepers of the access to information. Budapest: Pázmány Press, 2018.

3. 'Blocking access to content previously declared unlawful: a new obligation for online platforms?' Epra, 15 January 2020. Online: www.epra.org/news_items/blockingaccess-to-content-previously-declared-unlawful-a-new-obligation-on-the-platform

4. Borger, Julian, Lauren Gambino and Sabrina Siddiqui, 'Tech giants face Congress as showdown over Russia election meddling looms'. The Guardian, 22 October 2017. Online: www.theguardian.com/technology/2017/oct/22/facebook-google-twittercongress-hearing-trump-russia-election

5. Créer un cadre français de responsabilisation des réseaux sociaux: agir en France avec ambition européenne. Rapport de la mission 'Régulation des réseaux sociaux - Expérimentation Facebook', Secrétaire d'État chargé du numérique, 2019. Online: www.vie-publique.fr/sites/default/files/rapport/pdf/194000427.pdf

6. Eifert, Martin et al., 'Evaluation des NetzD im Auftrag des BMjV', 2020. Online: www. bmjv.de/SharedDocs/Downloads/DE/News/PM/090920_Juristisches_Gutachten_ Netz.pdf;jsessionid=1FC0BF32584A5F68718600E553FCDFEA.1_cid289?__ blob=publicationFile\&v=3

7. Gesetzentwurf der Fraktionen der CDU/CSU und SPD, Drucksache 19/17741. Online: https://dip21.bundestag.de/dip21/btd/19/177/1917741.pdf

8. Klein, Tamás, 'Adalékok az online diskurzusok szabályozási kérdéseihez', in Sajtószabadság és médiajog a 21. század elején, ed. by András Koltay and Bernát Török. Budapest: Wolters Kluwer, 2017, 156.

9. Koltay, András, New Media and Freedom of Expression: Rethinking the Constitutional Foundations of the Public Sphere. Hart Publishing, 2019. Online: https:/doi. org/10.5040/9781509916511

10. Prayank, '5 Ways Facebook Will Improve Transparency in Ads and Avoid Fake News'. Guiding Tech, 03 October 2017. Online: www.guidingtech.com/73648/facebook-adstransparency-enforcement

11. Ronfaut, Lucie, Enguérand Renault and Benjamin Ferran, 'Jack Dorsey (Twitter): «Les annonceurs attendent beaucoup de la vidéo». Le Figaro, 12 May 2016. Online: www. lefigaro.fr/secteur/high-tech/2016/05/12/32001-20160512ARTFIG00332-jack-dorseytwitter-les-annonceurs-attendent-beaucoup-de-la-video.php

12. Thielman, Sam, 'Facebook news selection is in hands of editors not algorithms, documents show'. The Guardian, 12 May 2016. Online: www.theguardian.com/ technology/2016/may/12/facebook-trending-news-leaked-documents-editorguidelines 
13. Tworek, Heidi and Paddy Leersen, 'An Analysis of Germany's NetzDG Law'. Transatlantic Working Group, 15 April 2019. Online: www.ivir.nl/publicaties/ download/NetzDG_Tworek_Leerssen_April_2019.pdf

14. Zuckerberg, Mark, 'The Internet Needs New Rules. Let's Start in These Four Areas'. The Washington Post, 30 March 2019. Online: www.washingtonpost.com/gdpr-cons ent/?destination=\%2fopinions $\% 2$ fmark-zuckerberg-the-internet-needs-new-ruleslets-start-in-these-four-areas\%2f2019\%2f03\%2f29\%2f9e6f0504-521a-11e9-a3f778b7525a8d5f_story.html\%3f

Balázs Bartóki-Gönczy is an Assistant Professor at the University of Public Service where he is head of Outer Space and Social Sciences Research Center. He has obtained Hungarian and French legal diplomas, specialised in telecommunications and space law. He holds an MBA (University Lyon 3) and a PhD degree (Péter Pázmány Catholic University). His main research has been concerned with space law, telecommunications law and regulatory questions of online media platforms. 